\title{
META ANALISIS : KATEGORI MODEL BIAYA KUALITAS DAN PROFITABILITAS
}

\author{
Desi Pujiati' $^{1)}$, Titi Nugraheni ${ }^{2}$, dan Misdiyono ${ }^{3)}$ \\ ${ }^{1,2,3}$ Jurusan Akuntansi, Fakultas Ekonomi, Universitas Gunadarma \\ ${ }^{1,2,3} \mathrm{Jl}$. Margonda Raya 100 Depok Jawa Barat - 16424 \\ E-mail : pujiati@staff.gunadarma.ac.id ${ }^{1)}$,Titi_n@staff.gunadarma.ac.id ${ }^{2)}$,Misdie@staff.gunadarma.ac.id ${ }^{3)}$
}

\begin{abstract}
ABSTRAK
Penelitian mengenai kategori model biaya kualitas dan profitabilitas memiliki persamaan dalam identifikasi, pengukuran dan pelaporan biaya kualitas. Perbedaan hasil penelitian terkait biaya kualitas ada pada tujuan penelitian terkait program perbaikan kualitas setiap perusahaan berbeda. Berdasarkan fenomena tersebut, peneliti melakukan meta analisis berdasarkan tujuan penelitian, variabel, obyek penelitian, populasi / sampel penelitian, teknik pengumpulan data, dan alat analisis yang digunakan. Penelitian ini bertujuan untuk mengetahui dan perkembangan penelitian mengenai model biaya kualitas dan profitabilitas. Penelitian ini menggunakan metode meta-analisis. Meta analisis merupakan telaah atas sejumlah hasil penelitian dalam masalah yang sejenis. Unit analisis dalam penelitian adalah dokumen-dokumen tertulis tentang penelitian model biaya kualitas yang berupa artikel jurnal dan laporan penelitian yang diambil secara purposive berdasarkan kesesuaiannya dengan tema penelitian. Analisis data yang digunakan adalah analisis data kuantitatif dengan prosentase dan analisis data kualitatif untuk data hasil analisis deskriptif terhadap 21 penelitian terkait model biaya kualitas. Temuan hasil meta analisis berdasarkan tujuan penelitian, variabel penelitian yang digunakan, populasi/sampel peneltian, teknik pengumpulan data dan alat analisis menunjukkan bahwa kategori model biaya kualitas dapat berkontribusi dalam mengevaluasi optimalisasi pencapaian kualitas.
\end{abstract}

Kata Kunci: Meta Analisis, Biaya Kualitas Dan Profitabilitas.

\section{PENDAHULUAN}

Kualitas telah menjadi suatu parameter yang sangat penting dalam menghadapi persaingan. Perusahaan yang harus memiliki daya saing untuk menjual produk dengan kualitas pada tingkat harga yang rendah. Konsekuensinya perusahaan tidak meningkatkan kualitas berdampak pada kehilangan pangsa pasarnya. Perbaikan kualitas secara terus-menerus merupakan sesuatu yang penting dalam membangun masa depan bisnis yang berkelanjutan (Sandag, Tinangon \& Waldanouw, 2014).

Kategori biaya kualitas memiliki pendekatan berbedabeda yang digunakan dala profitabilitas $m$ penelitian untuk pencapaian efisiensi dan produktivitas. Secara umum, model biaya kualitas dikategorikan menjadi empat kelompok yaitu; 1) P-A-F models: Prevention costs + Appraisal costs + Failure costs, 2) Crosby's model: Cost of conformance + Cost of non-conformance, 3) Opportunity or intangible cost models: [Prevention costs + Appraisal costs + Failure costs + Opportunity costs] / [Cost of conformance+ Cost of non-conformance + Opportunity costs] / [Tangibles + intangibles] / [P-A$F$ (failure costs includes opportunity costs)], 4) Process cost models: Cost of conformance + Cost of nonconformance. Pengembangkan model untuk mengukur biaya kualitas, yang memiliki lima kategori; biaya pencegahan, biaya penilaian, biaya kegagalan internal, biaya kegagalan eksternal, dan biaya daur ulang (Fayza, 2016).
Penelitian terkait dengan biaya kualitas sebagian besar penelitian penilaian kualitas biaya serupa satu sama lain. Penelitian biaya kualitas menyatakan ketergantungan tertentu dari perubahan biaya kualitas pada produk berkualitas tinggi atau pada beberapa proses individual. Biaya kualitas tidak dihitung secara eksplisit tetapi secara sederhana menyerap biaya overhead. Penelitian kualitatif terhadap biaya kualitas membutuhkan proses pengukuran dan pelaporan biaya kualitas (Daunoriene \& Staniskiene, 2016).

Penelitian biaya kualitas dalam proses pengambilan keputusan pada 4 kelompok biaya kualitas. Perbedaan hasil distribusi biaya kualitas dapat mengevaluasi dan proses pengambilan keputusan untuk perbaikan kualitas. Perbedaan penyerapan biaya kualitas terhadap alokasi prosentase penjualan pada pelaporan kegiatan adalah pendekatan yang semakin penting. Hal ini dilakukan untuk efektivitas keuangan yang berdampak pada perbaikan berkelanjutan dan peningkatan kinerja organisasi.

Penerapan biaya kualitas yang dilakukan oleh setiap perusahaan dalam upaya memenangkan persaingan antar produsen. Perbedaan penelitian mengenai tujuan penerapan biaya kualitas dimana membutuhkan biaya yang tinggi dan membuat produk yang berkualitas menjadi lebih sulit antara lain; 1) Kualitas yang baik menyebabkan peningkatan produksi, 2) Kualitas yang baik dapat efisiensi biaya kualitas, 3) Kualitas yang baik 
dapat meningkatkan profitabilitas. Analisis dan evaluasi dari biaya kualitas, ada banyak model yang memberikan gambaran realistis tentang efisiensi dan profitabilitas diimplementasikan sistem manajemen biaya kualitas (Holota, et al, 2016).

Penerapan pelaporan biaya kualitas itu sendiri bukanlah proses yang mudah di mana organisasi menghadapi banyak kesulitan selama periode implementasi. Ada kekurangan penelitian untuk mengeksplorasi kesulitan yang dihadapi oleh organisasi dalam pelaksanaan sistem pelaporan biaya kualitas terutama di negara-negara berkembang (Murugan \& Kanagi, 2011). Hal ini juga menjadi tantangan untuk menghasilkan produk / layanan berkualitas lebih baik dengan biaya lebih rendah (Mantri \& Jaju, 2016).

Penelitian ini berupa meta analisis kategori model biaya kualitas dan produktifitas. Meta analisis dilakukan untuk membantu peneliti pada fokus biaya kualitas pada persamaan identifikasi, pengukuran dan pelaporan tetapi hasil peneltiannya berbeda. Berdasarkan hal tersebut penelitian ini membahas mengenai hasil meta analisis berdasarkan tujuan penelitian, variabel penelitian, teknik pengumpulan data, obyek penelitian, populasi/sampel penelitian, teknik pengumpulan data dan analisis data.

\section{RUANG LINGKUP}

Pengembangan penelitian biaya kualitas telah banyak dilakukan oleh para praktisi dan akademisi di seluruh dunia. Berbagai artikel dan penelitian yang berupaya menggali penerapan biaya kualitas baik diadopsi pada perusahaan manufaktur dan jasa.

Penelitian bertema biaya kualitas diterapkan dengan kategori biaya kualitas yang berbeda-beda. Hasil distribusi biaya kualitas juga menghasilkan perbedaan implikasi pada efisiesi dan produktivitas. Berdasarkan hal tersebut, pentingnya dilakukan meta analisis fokus penelitian pada tema biaya kualitas. Adapun meta analisis pada biaya kualitas dibatasi pada jurnal yang bertema biaya kualitas. Perbedaan fokus penelitian berdasarkan tujuan penelitian, variabel penelitian, teknik pengumpulan data, obyek penelitian, populasi/sampel penelitian, teknik pengumpulan data dan analisis data.

Rencana hasil penelitian ini yaitu pertama, pembuatan meta analisis berdasarkan tujuan penelitian, variabel penelitian, obyek penelitian, teknik pengumpulan data, obyek penelitian, populasi/sampel penelitian, teknik pengumpulan data dan analisis data. Kedua menganalisis hasil meta analisis biaya kualitas untuk menjadi acuan peneliti selanjutnya yang ingin membuat jurnal dengan tema biaya kualitas. Ketiga menghasilkan saran penelitian bertema biaya kualitas dari hasil rasio terbesar.

\section{BAHAN DAN METODE}

Bahan yang digunakan pada penelitian ini berupa konsep dari biaya kualitas dan konsep profitabiltas. Konsep profitabilitas pada penelitian ini sebagai pencapaian dan penerapan biaya kualitas. Metode pada penelitian ini mengenai jenis penelitian, populasi/sampel penelitain, teknik pengumpulan data dan analisis kuantitatif.

\subsection{Konsep Biaya Kualitas Dan Profitabilitas}

Berikut adalah beberapan konsep dalam biaya kualitas dan profitabilitas

\subsubsection{Konsep Biaya Kualitas (costs of quality).}

Biaya kualitas adalah biaya yang terjadi atau mungkin akan terjadi karena adanya kualitas yang rendah (Baldric et al, 2013). Biaya kualitas adalah biaya yang terjadi atau mungkin akan terjadi karena kualitas yang buruk. Biaya ini pada umumnya berhubungan dengan penciptaan kualitas, pengidentifikasian, perbaikan dan pecegahan kerusakan (Samryn, 2012). Biaya kualitas adalah biaya - biaya yang timbul karena mungkin atau telah terdapat produk yang kualitasnya buruk (Hansen dan Mowen (2009).

Kategori biaya kualitas menurut Hansen dan Mowen (2009):

1. Biaya pencegahan (Prevention Cost)

Biaya pencegahan (prevention cost) adalah biaya yang dikeluarkan untuk mencegah terjadinya kerusakan kualitas. Biaya semua kegiatan yang dirancang khusus untuk mencegah kualitas buruk dalam produk atau jasa (Mantri \& Jaju, 2016).

2. Biaya penilaian (Appraisal Cost)

Biaya penilaian muncul untuk menentukan apakah produk atau jasa sesuai dengan kebutuhan konsumen atau spesifikasi mereka. Biaya terkait untuk memastikan kesesuaian standar kualitas dan kinerja (Mantri \& Jaju, 2016).

3. Biaya kegagalan Internal ( Failure Internal Cost)

Biaya kegagalan internal timbul karena produk atau jasa tidak sesuai dengan spesifikasi dan kebutuhan konsumen. Biaya kegagalan terjadi bila perlu untuk memperbaiki produk yang gagal memuaskan pelanggan atau tidak memenuhi spesifikasi kualitas perusahaan. Biaya kegagalan adalah kerugian yang terkait dengan produksi dari produk yang tidak sesuai (Abdelsalam dan Ghad, 2009).

4. Biaya kegagalan Eksternal ( Failure Eksternal Cost) Biaya kegagalan eksternal muncul karena produk atau jasa gagal memenuhi persyaratan. Biaya yang dikeluarkan untuk menghindari kegagalan untuk memenuhi harapan konsumen setelah produk atau jasa dikirim ke konsumen. Biaya yang terjadi karena produk atau jasa yang dihasilkan gagal memenuhi standar setelah produk tersebut sampai ke tangan pembeli. Sandag, Tinangon, Waldanouw, S, K, 2014)

\subsubsection{Profitabilitas}

Para pionir kualitas membuat penelitian tentang aspek ekonomi tentang kualitas jauh melebihi biayanya. Peningkatan kualitas dapat memberikan kepercayaan kepada pelanggan dan pada akhirnya mendorong 
peningkatan profitabilitas (Mohdanas dan Sankaranarayanan, 2008). Perusahaan dapat melakukan perencanaan biaya kualitas di masa yang akan datang dengan cara membuat stdanar biaya kualitas yang dapat ditentukan dengan mencari tingkat optimum dari biaya kualitas pada periode lalu. Dengan melakukan perencanaan biaya kualitas perusahaan bisa menekan pengeluaran untuk biaya kualitas tetapi tetap menghasilkan produk yang berkualitas pula sehingga penjualan pun akan terus meningkat (Gantino dan Erwin, 2009). Cara Kualitas meningkatkan profitabilitas tersaji pada Gambar 1

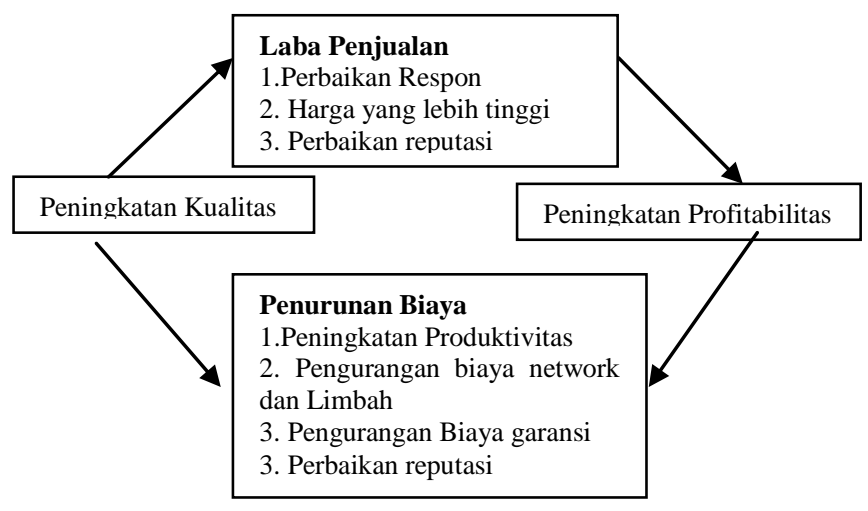

Gambar 1. Cara Kualitas meningkatkan Sumber: Heizer dan Render (2005)

\subsection{Tahapan Penelitian}

Jenis penelitian yang digunakan adalah meta-analisis. Meta analisis adalah penelitian yang dilakukan peneliti dengan cara merangkum data penelitian, mereview dan menganalisis data penelitian dari beberapa hasil penelitian yang sudah ada sebelumnya (Anugraheni, 2018) Teknik pengumpulan data akan menggunakan teknik dokumentasi.

Populasi dalam penelitian ini adalah semua dokumen tertulis mengenai penelitian penerapan biaya kualitas. Dokumen tertulis tersebut berupa: paper dan jurnal. Sampel penelitian diambil menggunakan teknik purposive sampling. Hal ini dikarenakan data atau informasi yang ingin diperoleh dari sampel ditentukan berdasarkan keterkaitan dengan tema penelitian ini. Analisis data yang digunakan adalah analisis data kuantitatif dengan prosentase dan analisis data kualitatif untuk data-data hasil telaah naratif terhadap penelitian yang berhasil di meta analisis.

\section{PEMBAHASAN}

Pembahasan pada penelitian ini menghasilkan hasil meta analisis berdasarkan tujuan penelitian, variabel penelitian, obyek penelitian, teknik pengumpulan data, obyek penelitian, populasi/sampel penelitian, teknik pengumpulan data dan analisis data. Hasil meta analisis akan dibahas sebagai acuan penelitian selanjutnya untuk menganalisis kategori model biaya kualitas dan produktifitas.

\subsection{Hasil Meta Analisis}

Penelitian tentang biaya kualitas dan profitabilitas yang didapatkan adalah sebanyak 20 penelitian. Penelitian sejenis diperoleh dari berbagai sumber, yaitu: paper dan jurnal. Secara umum data tersebut didapatkan dengan mengunduh dari internet. Adapun penelitian yang dijadikan meta analisis adalah peneliti sebagai berikut; Mohandas dan Sankaranarayanan (2108), Abdelsalam dan Ghad (2009), Jafar, et al, (2010), Mukhtar, et al (2010), Rasamanie dan Kanapathy (2011), Villara, Smith dan Simonton (2012), Khozein, Mohammadi dan Zarmehri (2013), Sahu dan Sridhar (2013), Kirlioglu dan Cevic (2013), Erviansyah (2013), Sandag, Tinangon dan Walandouw (2014), Marchel dan Ilat (2014), Sailaja, Basak dan Viswanadhan (2015), Daunoriene dan Staniskiene (2016), Fayza (2016), Mantri dan Jaju (2016), Holota,vet al (2017), Tumiwa dan Pontoh (2017), Neyestani dan Juanzon (2017), Tresnawati, Octavia dan Herawati (2017), Ningtyas dan Lubis (2018). Meta Analisis berdasarkan tujuan penelitian, variabel penelitian yang digunakan, obyek penelitian, populasi/sampel peneltian, teknik pengumpulan data dan alat analisis.

\subsection{Meta Analisis Berdasarkan Tujuan Penelitian}

Tujuan penelitian kategori model biaya kualitas diperoleh pada Mengindentifikasi optimalisasi pencapaian kualitas, hubungan dan pengaruh biaya kualitas, pengukuran dan pelaporan, penerapan/ pelaksanaan/ penetapan biaya kualitas. Berdasarkan kajian terhadap 21 penelitian dapat dihasilkan data sebagai berikut dalam Tabel 1 berikut ini.

Tabel 1. Tujuan dalam Penelitian

\begin{tabular}{|l|l|c|c|}
\hline No & \multicolumn{1}{|c|}{ Tujuan Penelitian } & Frekuensi & $(\%)$ \\
\hline 1. & $\begin{array}{l}\text { Mengindentifikasi } \\
\text { optimalisasi pencapaian } \\
\text { kualitas }\end{array}$ & 4 & $19 \%$ \\
\hline 2. & Hubungan dan pengaruh & 5 & $24 \%$ \\
\hline 3. & $\begin{array}{l}\text { Pengukuran dan } \\
\text { Pelaporan }\end{array}$ & 4 & $19 \%$ \\
\hline 4. & $\begin{array}{l}\text { Penerapan/ } \\
\text { Pelaksanaan/ Penetapan }\end{array}$ & 21 & $38 \%$ \\
\hline & Jumlah & $100 \%$ \\
\hline
\end{tabular}

Sumber : Diolah peneliti (2018)

\subsection{Meta Analisis Berdasarkan Variabel Penelitian}

Berdasarkan hasil meta analisis tujuan penelitian pada Tabel 1 menunjukkan 16 (76\%) penelitian deskriptif dan kuantitatif, maka meta analisis penelitian yang menggunakan variabel penelitian ada 5 (24\%) jurnal yang ditelaah. Adapun variabel independen yang digunakan biaya kualitas yang terdiri dari biaya pencegahan, biaya penilaian, biaya kegagalan internal dan biaya kegagalan eksternal. Penggunaan variabel dependen berbeda-beda. Berdasarkan kajian terhadap 5 
penelitian dapat dihasilkan data sebagai berikut dalam Tabel 2.

Tabel 2. Variabel Penelitian

\begin{tabular}{|l|l|c|c|}
\hline No & \multicolumn{1}{|c|}{ Variabel dependen } & Frekuensi & $(\%)$ \\
\hline 1. & Penjualan & 1 & $20 \%$ \\
\hline 2. & $\begin{array}{l}\text { Produk rusak } \\
\text { Biaya } \\
\text { internal Kegagalan }\end{array}$ & 1 & $20 \%$ \\
\hline 3. & Added Value Chain & 1 & $20 \%$ \\
\hline 4. & Profitabilitas & 1 & $20 \%$ \\
\hline 5. & Biaya Kualitas & 1 & \\
\hline & Jumlah & 5 & $20 \%$ \\
\hline
\end{tabular}

Sumber : Diolah peneliti (2018)

\subsection{Meta Analisis Berdasarkan Obyek Penelitian}

Obyek yang digunakan dalam penelitian biaya kualitas adalah pada 21 peneltian yang ditelaah bergerak pada industri manufaktur, perusahaan kontruks, perangkat lunak dan kuliner. Berdasarkan telaah terhadap 21 penelitian biaya kualitas dapat dilihat dalam Tabel 3 berikut ini.

Tabel 3. Obyek Penelitian

\begin{tabular}{|l|l|c|c|}
\hline No & \multicolumn{1}{|c|}{ Obyek Penelitian } & Frekuensi & $(\%)$ \\
\hline 1. & Industri Manufaktur & 16 & $76 \%$ \\
\hline 2. & Kontruksi & 3 & $14 \%$ \\
\hline 3. & Perangkat Lunak & 1 & $5 \%$ \\
\hline 3. & Kuliner & 1 & $5 \%$ \\
\hline & Jumlah & 21 & $100 \%$ \\
\hline
\end{tabular}

Sumber : Diolah peneliti (2018)

\subsection{Meta Analisis Berdasarkan Populasi dan Sampel Penelitian}

Populasi dan Sampel Penelitian yang digunakan dalam penelitian biaya kualitas adalah responden yang memiliki pengetahuan kualitas dan profesional kualitas. Berdasarkan kajian terhadap 21 penelitian biaya kualitas, maka responden yang dijadikan populasi dan dapat dilihat dalam Tabel 4 berikut ini.

Tabel 4. Populasi dan Sampel Penelitian

\begin{tabular}{|l|l|c|c|}
\hline No & \multicolumn{1}{|c|}{$\begin{array}{c}\text { Populasi/Sampel } \\
\text { Penelitian }\end{array}$} & Frekuensi & $(\%)$ \\
\hline 1. & Departemen Akuntansi & 4 & $19 \%$ \\
\hline 2. & $\begin{array}{l}\text { Manajer dan supervisor } \\
\text { aktif TQM }\end{array}$ & 17 & $81 \%$ \\
\hline & Jumlah & 21 & $100 \%$ \\
\hline
\end{tabular}

Sumber : Diolah peneliti (2018)

\subsection{Meta Analisis Berdasarkan Teknik pengumpulan data}

Teknik pengumpulan data yang digunakan dalam penelitian biaya kualitas terdiri atas: metode studi literatur, observasi, survei, dokumentasi, kuesioner, dan wawancara. Berdasarkan telaah terhadap 21 penelitian tentang biaya kualitas, maka teknik pengumpulan data yang digunakan dapat dilihat dalam Tabel 5.

Tabel 5. Teknik Pengumpulan Data

\begin{tabular}{|c|l|c|c|}
\hline No & \multicolumn{1}{|c|}{$\begin{array}{c}\text { Teknik pengumpulan } \\
\text { Data }\end{array}$} & Frekuensi & $(\%)$ \\
\hline 1. & Survei dan dokumentasi & 10 & $48 \%$ \\
\hline 2. & Survei dan Kuesioner & 4 & $19 \%$ \\
\hline 3. & $\begin{array}{l}\text { Survei , Wawancara } \\
\text { Dokumentasi }\end{array}$ & 4 & $19 \%$ \\
\hline 4. & $\begin{array}{l}\text { Studi Literatur } \\
\text { Dokumentasi }\end{array}$ & 3 & $14 \%$ \\
\hline & \multicolumn{1}{|c|}{ Jumlah } & 21 & $100 \%$ \\
\hline
\end{tabular}

Sumber : Diolah peneliti (2018)

\subsection{Meta Analisis Berdasarkan Analisis data}

Analisis data yang digunakan dalam penelitian biaya kualitas terdiri atas; analisis ekplanatif, analisis pareto, analisis deskriptif, analisis kuantitatif, korelasi dan regresi. Berdasarkan telaah terhadap 21 penelitian tentang biaya kualitas, maka analisis data yang digunakan dapat dilihat dalam Tabel 6 . berikut ini.

Tabel 6. Analisis Data

\begin{tabular}{|l|l|c|c|}
\hline No & \multicolumn{1}{|c|}{ Analisis Data } & Frekuensi & $(\%)$ \\
\hline 1. & Analisis Pareto & 2 & $10 \%$ \\
\hline 2. & Analisis korelasi & 1 & $5 \%$ \\
\hline 3 & Regresi & 3 & $14 \%$ \\
\hline 4. & Analisis Eksplanatif & 2 & $10 \%$ \\
\hline 5. & $\begin{array}{l}\text { Analisis Deskriptif } \\
\text { Analisis Komparatif }\end{array}$ & 2 & $10 \%$ \\
\hline 6. & $\begin{array}{l}\text { Analisis Deskriptif } \\
\text { Anova }\end{array}$ & 1 & $5 \%$ \\
\hline 7. & $\begin{array}{l}\text { Analisis Deskriptif } \\
\text { Analisis Kuantitatif }\end{array}$ & 7 & $32 \%$ \\
\hline 8. & $\begin{array}{l}\text { Analisis Pareto } \\
\text { Korelasi } \\
\text { Regresi }\end{array}$ & 3 & $14 \%$ \\
\hline & Jumlah & 21 & $100 \%$ \\
\hline
\end{tabular}

Sumber : Diolah peneliti (2018)

\subsection{Analisis Hasil Meta Analisis}

Penelitian tentang biaya kualitas berdasarkan tujuan penelitian diperoleh rasio terbesar meneliti mengenai penerapan/ pelaksanaan/ penetapan biaya kualitas. Hal ini membuktikan bahwa penerapan/ pelaksanaan/ penetapan biaya kualitas dapat menganalisis dan mengevaluasi pencapaian produk berkualitas. Pencapaian produk berkualitas perusahaan yang diperoleh dari penerapan biaya kualitas berdampak efisiensi dan profitabilitas. Hasil pembuktian tersebut dapat dijadikan referensi bagi peneliti bidang biaya kualitas untuk mengembangkan penelitian dengan model biaya kualitas untuk pencapaian produk yang berkualitas untuk meningkatkan profitabilitas. Rasio kedua terbesar meta analisis yang memiliki tujuan penelitian yang hubungan dan pengaruh biaya kualitas untuk optimalisasi pencapaian kualitas. Hal ini dapat membuktikan bahwa 
biaya kualitas memiliki hubungan dan pengaruh terhadap penjualan, produk rusah, nilai tambah dan produktifitas. Rasio ketiga dan keempat terbesar meta analisis yang memiliki tujuan penelitian yang mengindentifikasi, pengukuran dan pelaporan. Hal ini dapat membuktikan bahwa penelitian biaya kualitas masih menarik untuk diteliti karena biaya kualitas merupakan tujuan perusahaan dalam pencapaian produk berkualitas dan profitabilitas.

Penelitian tentang biaya kualitas rasio terbesar penelitian deskriptif dan kuantitatif. Hal ini membuktikan bahwa proses pengindentifikasian, pengukuran dan pelaporan biaya kualitas merupakan tahapan dalam penerapan/pelaksanaan/ penetapan biaya kualitas. Berdasarkan hasil penerapan biaya kualitas dapat digunakan untuk menganalisis dan mengevaluasi pencapaian produk berkualitas yang berdampak pada profitabilitas. Berdasarkan variabel penelitian diperoleh dari 5 jurnal yang mengunakan analisis regresi memiliki rasio yang sama. Adapun variabel dependen yang dibahas mengenai penjualan, produk rusak, biaya kegagalan internal, Added Value Chain dan Profitabilitas. Hal ini membuktikan bahwa biaya kualitas memiliki andil terhadap meningkatkan penjualan, menurunkan produk rusak dan memperkecil kegagalan internal. Hasil ini dapat berpengaruh juga terhadap pencapaian nilai tambah pada proses dan hasil produksi.

Penelitian tentang biaya kualitas berdasarkan obyek penelitian diperoleh rasio terbesar meneliti menggunakan obyek penelitian pada industri manufaktur. Hal ini membuktikan bahwa proses pengindentifikasian biaya kualitas diawali dari sebelum proses produksi, proses produksi, barang jadi dan barang sampai ke konsumen. Hasil penerapan biaya kualitas pada industri manufaktur sejalan dengan tujuan perusahaan dalam menciptakan produk berkualitas agar bisa berkompetisi. Rasio terbesar kedua adalah obyek pada perusahaan konstruksi. Hal ini membuktikan perusahaan kontruksi memiliki standarisasi bahan bangunan, sumber daya yang berkompeten dibidang teknik, proses pelaksanaan memiliki prosedur sampai pada hasil proyek pembangunan. Rasio ketiga dan keempat biaya kualitas juga mulai diteliti pada produk perangkat lunak dan kuliner. Hal ini membuktikan bahwa bisnis perangkat lunak dan sejalan dengan penelitian Safi'i dan Vidy (2017) dimana pentingnya penjaminan mutu berbasis web. Bisnis kuliner juga harus membutuhkan pengindentifikasian, pengukuran dan pelaporan biaya kualitas untuk menghasilkan produk dengan kualitas cita rasa, pelayanan dan penyajian untuk bisa berkompetisi.

Penelitian tentang biaya kualitas berdasarkan populasi/sampel penelitian diperoleh rasio terbesar responden pada manajer dan supervisor aktif TQM. sebanyak $81 \%$. Hal ini membuktikan bahwa professional yang terlibat pada proses pengawasan kualitas pada industri manufaktur memiliki pengetahuan kualitas produk. Rasio kedua terbesar populasi/sampel penelitian ini adalah level manajemen pada departemen akuntansi.
Hal ini membuktikan bahwa penerapan biaya kualitas dibutuhkan peran manajemen departemen akuntansi dalam proses pengindentifikasian, pengukuran dan pelaporan biaya kualitas.

Penelitian tentang biaya kualitas berdasarkan teknik pengumpulan data diperoleh rasio terbesar menggunakan survei dan dokumentasi. Hal ini membuktikan bahwa data biaya kualitas diperoleh melalui survei ke perusahaan yang memiliki standar produk dalam menghasilkan produk berkualitas. Teknik dokumentasi juga diperlukan untuk memperoleh data kuantitatif biaya kualitas. Data kuantitatif diperoleh berupa sertifikasi karyawan, sertifikasi proses produksi, hasil uji rekayasa kualitas, biaya perawatan mesin terkait produksi, dan banyak lainya. Rasio kedua terbesar teknik pengumpulan data survei dan kuesioner. Kuesioner dibutuhkan pada penelitian biaya kualitas karena perusahaan memiliki standar kualitas, namun dalam pengindentifikasi, pengukuran bahkan pelaporan belum terdokumentasi dengan baik. Hal ini teknik pengumpulan data yang dilakukan oleh peneliti memperoleh data melalui kuesioner. Metode survei, wawancara dan dokumentasi juga menghasilkan rasio kedua terbesar. Metode ini dilakukan penelitian ada perolehan data melalui survei, melalui kuesioner dan dokumentasi. Hal ini membutktikan bahwa data untuk memperoleh informasi biaya kualitas ada yang kualitatif dan kuantitatif. Rasio ketiga pada teknik pengumpulan data pada penelitian biaya kualitas adalah studi literature dan dokumentasi. Hal ini mejadi dilakukan peneliti karena masih terdapat perbedaan hasil analisa. Perbedaan ini membuktikan bahwa masing-masing perusahaan memiliki standar kualitas yang berbeda-beda dan program perbaikan yang dilakukan perusahaan waktu yang berbeda pada pelaksanaannya.

Penelitian tentang biaya kualitas berdasarkan analisis data diperoleh rasio terbesar analisis dekriptif dan analisis kuantitatif. Hal ini dibutuhkan bagi peneliti dari cara dominan pengumpulan data melalui survei dan dokumentasi. Analisis deskriptif ini digunakan untuk menjelaskan hasil olah data pengindentifikasian dan pengukuran biaya kualitas. Hasil penjelasan deskriptif di dukung dengan data dari dokumentasi untuk pelaporan dan distribusi biaya kualitas. Hasil pelaporan dan distribusi ini dapat dijadikan acuan mengevaluasi pencapaian produk berkualitas dan berdampak pada profitabilitas. Rasio kedua terbesar pada alat analisis penelitian biaya kualitas adalah analisis regresi. Analisis regresi digunakan peneliti dapat mengetahui jenis biaya kualitas mana yang paling berpengaruh terhadap penjualan, produk rusak, biaya kegagalan internal, Added Value Chain dan Profitabilitas. Hal ini dapat dijadikan proses pengambilan keputusan terhadap program standarisasi dan perbaikan kualitas produk. Rasio ketiga terbesar yaitu. analisis pareto, korelasi dan regresi. Ketiga analisis ini digunakan peneliti biaya kualitas sebagai tahapan penelitian yang komprehensif. Hasil analisis pareto dilakukan untuk melihat distribusi 
jenis biaya kualitas. Hasil analisis pareto ini diolah kembali pada alat analisis korelasi dan regresi, untuk melihat jenis biaya kualitas mana yang berhubungan/ memiliki pengaruh terhadap perbaikan kualitas dan berdampak pada profitabilitas.

\section{KESIMPULAN}

Berdasarkan hasil pembahasan pada penelitian ini, maka dapat disimpulkan meta analisis terhadap 21 jurnal terkait kategori model biaya kualitas dan profitabilitas dihasilkan tujuan Penelitian tentang biaya kualitas rasio terbesar pada untuk penerapan/ pelaksanaan/ penetapan biaya kualitas. Meta analisis berdasarkan variabel dependen penelitian memiliki rasio yang sama, yaitu mengenai penjualan, produk rusak, biaya kegagalan internal, Added Value Chain dan Profitabilitas. Meta analisis berdasarkan obyek penelitian diperoleh rasio terbesar meneliti menggunakan obyek penelitian pada industri manufaktur. Meta analisis berdasarkan populasi/sampel penelitian diperoleh rasio terbesar responden pada manajer dan supervisor aktif TQM. Meta analisis berdasarkan teknik pengumpulan data diperoleh rasio terbesar menggunakan survei dan dokumentasi. Meta analisis berdasarkan analisis data diperoleh rasio terbesar analisis dekriptif dan analisis kuantitatif.

\section{SARAN}

Hasil pembahasan dan kesimpulan pada penelitian ini, dapat menjadi acuan peneliti selanjutnya mengenai penelitian terkait biaya kualitas berdasarkan tujuan penelitian, variabel penelitian, obyek penelitian, teknik pengumpulan data, obyek penelitian, populasi/sampel penelitian, teknik pengumpulan data dan analisis data.

\section{DAFTAR PUSTAKA}

Abdelsalam dan Ghad. 2009. Cost of Quality in Dubai: An Analytical Case Study of Residential Construction Projects. International Journal of Project Management, 4(1), 40-52.

Anugraheni, H. 2018. Meta Analisis Model Pembelajaran Problem Based Learning dalam Meningkatkan Keterampilan Berpikir Kritis di Sekolah Dasar. A Journal of Language, Literature, Culture, and Education, 14(1), 9-18.

Daunoriene, A dan Staniskiene, E, (2016), The Quality Costs Assessment in the Aspect of Value Added Chain. Quality Innovation Prosperity, 2(2), 119145.

Erviasyah, A. (2013). Analisis Pengaruh Biaya Kualitas Terhadap Produk Rusak Pada PT. Nusa Toyotetsu Corporation. Management Analysis Journal, November, 1-7

Fayza,M. (2016). Quality Cost dan Its Relationship to Revenue Sh aring in Supply Chain. Accounting dan Finance Research, 5(3), 174-189.

Gantino R., dan Erwin. (2009). Pengaruh Biaya Kualitas terhadap Penjualan pada PT.Guardian
Pharmatama. Journal of Applied Finance dan Accounting, 2(2), 138-168.

Hansen R. D., dan Mowen M,M. (2009). Akuntansi Manajemen. Buku 2, Edisi 8, Jakarta: Penerbit Salemba Empat.

Heizer, J., dan Render, B. (2015). Operations Nabajemen (Manajemen Operasi) edisi 11, penterjemah: Dwi Anugerah Watu S dan Undra Almahdy, Salemba Empat.

Holota, M, H., J dan Kotusa, M. (2016). The Management Of Quality Costs Analysis Model. Serbian Journal of Management, 11(1), 119 127.

Jafar, A., Mohammad, T., F., dan Fariba, E. (2010). Effect of the Quality Costing System on Implementation dan Execution of Optimum Total Quality Management. International Journal of Business dan Management, 5(8), 1926.

Jafari, A., dan Heravi, G. (2011). PAF Model for Quality Cost Estimation in Mass-Housing Projects. Construction. Challenges in the New Decade, $1-8$.

Kirlioglu, H., dan Cevic, Z. (2013). Measuring dan Reporting Cost of Quality in a Turkish Manufacturing Company: A Case Study in Electric Industry. Journal of Economic dan Social Studies, 3(2), 87-99.

Khozein, A., Mohammadi, J., \& Zarmehri, M, A. 2013. Cost of quality and quality optimization in manufacturing. European Online Journal of Natural and Social Sciences, 2(3).Hal 10701081 .

Ningtyas, H., \& Lubis,H, Z. 2018. Pengaruh Biaya Kualitas Terhadap Jumlah Penjualan. Jurnal Riset Akuntansi \& Bisnis, 18(1), 1-13.

Mantri, S., \& Jaju, S. (2016). Cost Of Quality Management in Indian Industries: A Practical Insight. International Journal for Quality Research, 11(3), $491-506$.

Marchel, S .M ,T., \& Ilat, V. (2014). Penerapan Biaya Kualitas untuk Meningkatkan Efisiensi Produksi Pada UD. Sinar Sakti Manado. Jurnal EMBA, 2(2), 1712-1722.

Mohandas V, P., \& Sankaranarayanan, S, R.(2008). Cost of Quality Analysis: Driving Bottom-line Performance. International Journal of Strategic Cost Management, 3(2), 1-8.

Safi'i \& Vidy. 2017. Perancangan Sistem Informasi Badan Penjaminan Mutu Internal STMIK Balikpapan Berbasis Website Responsive. METIK Jurnal, 1(2), 1-7.

Mukhtar, C., Ali, R., Md Z., Hamid, Z,A., \% Ayub, A, R. (2010). Quality Cost in The Contruction Industry-Preliminary Findings in Malaysia. Journal of Design and Built Environment, 6 (6), 29-43. 
Murugan, R., \& Kanagi, K. (2011). The Implementation of Cost of Quality (COQ) Reporting System in Malaysian Manufacturing Companies : Difficulties Encountered dan Benefits Acquired. International Journal of Business dan Social Science. 2(6), 243-247.

Neyestani, B., Juanzon, J, B,P., \& Joseph B, P. (2017). Impact of ISO 9001 Standard on the Quality Cost ofConstruction Projects in the Philippines. Manila International Conference on Trends in Engineering and Technology. January, 2324,55-63.

Ramadhan, S., \& Bucheery, R. (2005). Quality Management Through ISO Certification And Quality Costs Reporting: A Study Of Bahraini Companies. International Business \& Economics Research Journal, 4(9), 11-26.

Rasamanie, M., \& Kanapathy. (2011). The Implementation of Cost of Quality (COQ) Reporting System in Malaysian Manufacturing Companies : Difficulties Encountered dan Benefits Acquired. International Journal of Business dan Social Science, 2(6), 243-247.

Sahu, N, M., \& Sridhar. (2013). Development of Model for Quality Costing in a Medium Scale Industry - A case study. International Organization Of Scientific Research Journal of Mechanical dan Civil Engineering, 6(4), 19-23.

Sailaja, A., Basak, P, C., \& Viswanadhan, K, G. (2015). Costs of Quality: Exploratory Analysis of Hidden Elements dan Prioritization using Analytic Hierarchy Process. International Journal of Supply and Operations Management, 1(4), 489-506.

Sandag, N,E., Tinangon, J., \& Waldanouw, S, K. (2014). Analisis Biaya Kualitas dalam Meningkatkan Profitabilitas Perusahaan pada CV Ake Abadi Manado. Jurnal EMBA 1327, 2(2), 1327-1337.

Sugiyono. 2014. Metodologi Penelitian Kuantitatif, Kualitatif dan rasio. Alfabeta: Bandung.

Theresia, C., \& Pontoh, W,T. (2017). Penerapan Biaya Kualitas untuk Meningkatkan Efisiensi Produksi pada Dolphin Donut Bakaery. Jurnal EMBA. 5 (2), $2051-2060$.

Tresnawati, R., Octavia, E., \& Herawati, S, S. (2017). The Effect of Efficiency and Quality Cost on Profitability. Review of Integrative Business and Economics Research, 6(1), 296-304.

Villara, K, C., Smith, N, R., \& Simonton, J, L. (2012). The Impact of the Cost of Quality on Serial Supply-Chain Network Design. International Journal of Production Research, 50 (19), 55445566. 